\title{
PERANAN ADVOKAT SEBAGAI PENEGAK HUKUM DALAM SISTEM PERADILAN PIDANA DIKAJI MENURUT UNDANG-UNDANG NOMOR 18 TAHUN 2003 TENTANG ADVOKAT
}

\author{
Mumuh M Rozi \\ Dosen Fakultas Hukum Universitas Suryakancana
}

\begin{abstract}
ABSTRAK
Advokat merupakan penegak hukum dan sebagai profesi yang bebas, mandiri dan bertanggung jawab dalam menegakkan hukum yang dijamin oleh Undang-undang. Itu berarti bahwa advokat memiliki hak, kewajiban dan tanggung jawab sesuai dengan aturan perundang-undangan advokat. Menurut Undang-Undang Nomor 18 Tahun 2003 tentang Advokat, ditegaskan bahwa, Advokat adalah orang yang berprofesi memberikan jasa hukum baik di dalam maupun di luar Pengadilan. Jasa hukum yang dimaksud adalah jasa yang diberikan advokat berupa memberikan konsultasi hukum, bantuan hukum, menjalankan kuasa, mewakili, mendampingi, membela dan melakukan tindakan hukum lain untuk kepentingan klien.
\end{abstract}

Kata Kunci : Penegakan Hukum, Advokat, Pengadilan, Konsultasi Hukum.

\section{ABSTRACT}

Advocate is a law enforcement and a free, independent and responsible job in enforcing the law guaranteed by law. It means that lawyers have rights, obligations and responsibilities in accordance with the rules of law advocates. According to Law No. 18 Year 2003 concerning Advocates, insisted that, Advocate is a person who is providing legal services both inside and outside the court. Legal services in question are services rendered in the form of lawyers providing legal advice, legal assistance, exercise the power, represent, assist, defend and perform other legal actions in the interests of the client.

Keywords: Law Enforcement, Advocate, Court, Legal Advice.

\section{PENDAHULUAN.}

Masalah penegakan hukum di Indonesia merupakan topik yang senantiasa menarik untuk diperbincangkan. Penegakan hukum yang dari dahulu hanya merupakan proses yang tidak menemukan hasil akhir menyebabkan perbincangan yang baik dalam kajian yang formal maupun non-formal. 
Adanya ketidak sesuaian antara harapan dan kenyataan dari bekerjanya hukum menyebabkan penegakan hukum kembali dipertanyakan, hukum belum menemukan tujuan hakikinya. Faktor-faktor yang bersifat non-hukum diduga sebagai penyebab yang berdampak pada penegakan hukum diskriminatif, inkonsistensi dan ketidakpastian (unjust) yang pada akhirnya menimbulkan ketidakharmonisan masyarakat terhadap hukum terlebih pada aparat penegak hukumnya. Penegakan hukum sering dilakukan tidak dalam kerangka sistem, sehingga kebijakan penegakan hukumnya pun ditetapkan secara non sistem. ${ }^{1}$

Penegakan hukum merupakan fokus utama dalam proses reformasi dalam rangka mewujudkan keadilan bagi masyarakat dalam Negara Kesatuan Republik Indonesia (NKRI). ${ }^{2}$ Berbicara masalah penegakan hukum tidak terlepas dari permasalahan bagaimana hukum dapat berfungsi sesuai dengan yang diharapkan. Penegakan hukum pada hakikatnya merupakan proses penyesuaian antara nilai-nilai, kaidah-kaidah dan pola prilaku nyata yang bertujuan untuk mencapai kedamaian. ${ }^{3}$ Adapun faktor-faktor yang mempengaruhi di dalam penegakan hukum adalah, 1) Faktor hukumnya itu sendiri; 2) Faktor penegak hukum, yakni pihak-pihak yang membentuk maupun yang menerapkan hukum; 3) Faktor sarana dan fasilitas yang mendukung penegakan hukum; 4) Faktor masyarakat yakni lingkungan dimana hukum tersebut berlaku dan diterapkan; dan 5) Faktor kebudayaan, yakni sebagai hasil karya, cipta dan rasa yang didasarkan pada karsa manusia di dalam pergaulan hidup. ${ }^{4}$

Kelima komponen di atas sesungguhnya tidak dapat dipisahkan. Oleh karena itu, untuk mencapai keberhasilan dalam penegakan hukum, sangat tergantung sekali

1 Widiada Gunakaya, Pendekatan Sistem dan Kebijakan Dalam Penegakan Hukum di Indonesia, Jurnal Wawasan Hukum, Vol. 7 No. 1 Maret 2002. hlm. 58.

2 Esmi Warasih, Pemberdayaan Masyarakat Dalam Mewujudkan Tujuan Hukum, Pidato Pengukuhan Guru Besar Madya Dalam Ilmu Hukum, Fakultas Hukum Universitas Diponegoro, Semarang, 14 April 2002. hlm. 2.

3 Soerjono Soekanto, Faktor-faktor yang Mempengaruhi Penegakan Hukum, PT. Rajawali, Jakarta, 1983. hlm. 5

4 Ibid. 
pada eksistensi, artikulasi, performance dan harmonisasi dari komponen-komponen tersebut, dari kelima komponen di atas yang benar-benar dirasakan oleh masyarakat bahwa penegakan hukum tidak berjalan sesuai dengan harapan adalah lemahnya faktor penegak hukum itu sendiri. Seringkali masyarakat mengatakan bahwa sebaikbaiknya aturan, tanpa didukung oleh aparat penegak hukum yang baik, tidak akan berjalan dengan baik, dan sebaliknya, meskipun hukum mempunyai kelemahankelemahan secara substantif, apabila dilaksanakan/ditegakkan oleh aparat penegak hukum yang baik, maka akan hasilnya akan baik pula.

Lembaga penegak hukum yang umumnya dikenal masyarakat yakni Kepolisian, Kejaksaan dan Kehakiman. Bekerjanya aparatur dari ketiga institusi tersebut sering diistilahkan sebagai penegakan hukum dalam arti sempit. Sedangkan dalam arti luas, selain ketiga lembaga tersebut juga masyarakat termasuk ke dalam komponen penegak hukum. Bekerjanya/berfungsinya ketiga lembaga penegak hukum tersebut tampak sekali dalam sistem peradilan pidana (criminal justice sistem). Sistem peradilan pidana di Indonesia menganut konsep bahwa kasus-kasus pidana merupakan sengketa antara individu dengan masyarakat atau publik. ${ }^{5}$

Lebih lanjut Muladi menulis bahwa penegakan hukum (law enforcemet) merupakan suatu usaha untuk menegakkan norma-norma hukum dan sekaligus nilainilai yang ada dibelakang norma tersebut. Untuk itu, para penegak hukum harus memahami benar-benar spirit hukum yang mendasari peraturan hukum yang harus ditegakkan dan dalam hal ini akan bertalian dengan berbagai dinamikayang terjadi dalam proses pembuatan perundang-undangan (law making proses). Menurut Muladi selanjutnya penegakan hukum yang ideal harus disertai dengan kesadaran bahwa penegakan hukum merupakan sub-sistem sosial, sehingga pengaruh lingkungan cukup berarti, seperti pengaruh perkembangan politik, ekonomi, sosial budaya,

5 Soedjono Dirdjosisworo, Pelaksanaan Misi Advokat Dalam Peradilan Pidana, Makalah Pada Pelatihan Calon Advokat, Bandung, 2005. hlm. 1. 
hankam, iptek, pendidikan dan sebagainya. ${ }^{6}$ Pada sistem peradilan pidana di Indonesia, kewenangan untuk memeriksa dan mengadili perkara dilakukan oleh mahkamah (badan peradilan) yang dipimpin oleh Hakim tunggal maupun majelis, dalam persidangan, Jaksa berperan sebagai penuntut umum yang bertugas menuntut terdakwa yang didampingi oleh Pembela (Advokat). ${ }^{7}$

Maka pernyataan di atas, tampak bahwa selain Hakim dan Penuntut Umum, terdapat satu komponen yang turut ambil bagian dalam sistem peradilan pidana, yakni Advokat. Apabila ditinjau dari konsep sistem peradilan pidana di Indonesia, bahwa sistem peradilan pidana Indonesia menganut konsep bahwa sengketa-sengketa pidana merupakan sengketa antar individu dengan masyarakat, maka tampak jelas bahwa Jaksa Penuntut Umum merupakan pihak yang bertindak atas nama negara mewakili kepentingan masyarakat. Sementara advokat merupakan pendamping yang berusaha membela kepentingan terdakwa di persidangan. Undang-Undang Nomor 18 Tahun 2003 Tentang Advokat secara eksplisit menegaskan bahwa, status Advokat adalah Penegak Hukum dan sebagai penegak hukum bebas dan mandiri. (Pasal 5 ayat 1). Dari bunyi pasal tersebut dapat ditarik pengertian bahwa, meskipun advokat berada dipihak terdakwa (dipengadilan), akan tetapi dalam kapasitasnya sebagai penegak hukum, advokat harus membela kepentingan-kepentingan hukum.

Kenyataan di masyarakat memposisikan Advokat sebagai pihak yang membela kepentingan tersangka/terdakwa, sehingga ketika dalam proses peradilan (pidana), ketika seorang terdakwa berdasarkan putusan hakim dinyatakan bebas, maka opini masyarakat mengarah pada Advokat yang membela kepentingan pribadi tersangka/terdakwa dan bukan kepentingan hukum. Bahkan tidak jarang, advokat dicap sebagai pihak yang menjembatani mafia peradilan antara tersangka/terdakwa dengan aparat penegak hukum (Polisi, Jaksa dan Hakim).

6 Muladi, Hak Asasi Manusia, Politik dan Sistem Peradilan Pidana, Badan Penerbit Universitas Diponegoro, Semarang, 1997. HIm. 58.

7 Ibid. 


\section{PEMBAHASAN.}

\section{A. Ruang Lingkup Penegakkan Hukum di Indonesia.}

Istilah penegakan hukum sekarang ini menjadi pembicaraan. Penegakkan hukum sebagai bagian dari reformasi hukum karena dalam pembahsan reformasi hukum berarti reformasi hukum secara luas tidak hanya peraturan perundangundangan saja, tetapi mencakup reformasi sistem hukum secara keseluruhan yaitu reformasi materi/substansi hukum, struktur hukum dan budaya hukum. Bahkan secara lebih luas lagi masalah reformasi hukum dan keadilan sebenarnya bukan semata-mata masalah sistem hukum tetapi terkait dengan keseluruhan sistem politik dan sistem sosial termasuk sistem ekonomi. ${ }^{8}$

Reformasi di bidang penegakan hukum dan struktur hukum harus ada dukungan dari berbagai elemen/unsur pemerintah maupun masyarakat karena penegakan hukum merupakan rangkaian proses yang cukup panjang dan dapat melibatkan berbagai kewenangan instansi/aparat penegak hukum lainnya di bidang penegakan hukum pidana, dengan demikian reformasi penegakan hukum, bukan semata-mata merupakan tanggung jawab bidang Departemen Hukum dan Perundangundangan saja, melainkan perlu dukungan berbagai komponen lembaga terkait lainnya seperti Mahkamah Agung, Jaksa Agung, Kepolisian dan lainnya. ${ }^{9}$ Penegakan hukum ditinjau dari sudut pandang fungsional atau bekerjanya/berfungsinya sistem pemidanaan dapat diartikan sebagai keseluruhan sistem peraturan perundangundangan untuk fungsionalisasi/operasionalsasi/konkretisasi hukum pidana atau keseluruhan sistem yang mengatur bagaimana hukum pidana ditegakkan atau diperasionalkan sehingga seseorang dijatuhi sanksi pidana. ${ }^{10}$

8 Barda Nawawi Arief, Masalah penegakan Hukum dan Kebijakan Penaggulangan Kejahatan, Makalah pada Program Magister Ilmu Hukum Universitas Diponegoro, Semarang, 2000. hlm. 2.

Ibid. hlm. 3.

10 Barda Nawawi Arief, Sistem Pemidanaan Dalam Ketentuan Umum Buku I RUU KUHP 2004, "Makalah", disajikan pada acara Silaturahmi Akademik, Sekolah Tinggi Hukum Bandung, Bandung 12 Juli 2005. 
Penegakan hukum pidana merupakan satu sistem di mana dalam penegakkan hukum pidana bekerja sub sistem hukum pidana materiil/substantif, sub-sistem hukum pidana formal dan sub-sistem hukum pelaksanaan pidana. Ketiga sub sistem itu merupakan satu kesatuan dalam penegakkan hukum pidana karena tidak mungkin hukum pidana dioperasionalkan/ ditegakkan secara konkret hanya dengan salah satu sub sistem itu. ${ }^{11}$

Penegakkan hukum acara pidana, maka istilah hukum acara pidana merupakan istilah yang popular di mana pihak-pihak yang berperan langsung dalam penegakan hukum pidana, khususnya hukum pidana formil karena seluruh tugas, fungsi dan kewenangannya tercantum dalam KUHAP. Istilah lain yang popular dalam kaitannya dengan penegakan hukum pidana adalah criminal justice sistem yang diterjemahkan ke dalam bahasa Indonesia menjadi sistem peradilan pidana. Di Indonesia digunakan istilah "sistem peradilan pidana terpadu" sebagai salinan dari istilah integrated criminal justice sistem. ${ }^{12}$

Istilah hukum acara pidana mempunyai lingkup yang lebih sempit daripada sistem peradilan pidana karena dalam penegakkan hukum acara pidana hanya membahas bagaimana bekerjanya aparat penegak hukum yang dalam hal ini Polisi, Penuntut Umum, Hakim dan Penasehat Hukum dalam mencari dan menemukan kebenaran. Sementara masalah pembinaan narapidana tidak termasuk ke dalam hukum acara pidana, apalagi yang menyangkut perencanaan perundang-undangan pidana. Hukum pidana formil atau hukum acara pidana adalah hukum yang mengatur tentang bagaimana negara melalui alat-alatnya melaksanakan haknya untuk memidana dan menjatuhkan sanksi pidana. ${ }^{13}$

Perlu diperhatikan, bahwa penegakkan hukum dilaksanakan melalui berbagai jalur dengan sanksinya sebagai daya pengikat dari suatu peraturan perundangundangan yakni bahwa penegakkan hukum dilaksanakan melalui jalur pengadilan dan

11 lbid.

12 Andi Hamzah, Hukum Acara Pidana Indonesia, Sinar Grafika, Jakarta, 2006. hlm. 2.

13 D. Simons, Beknopie Handleiding tot het Wetboek van Strafvordering, dikutip dari Andi Hamzah, Ibid. hlm. 4. 
luar pengadilan. Penegakkan hukum melalui jalur pengadilan dilaksanakan dengan berbagai sanksi yang akan menimpa siapa saja yang melanggarnya. Sanksi-sanksi tersebut adalah: pidana, perdata dan sanksi administratif. Secara sederhana penegakkan hukum dapat diartikan sebagai upaya-upaya yang dilakukan agar hukum dapat berfungsi, beroperasi dan berwujud secara konkrit. Berdasarkan pengertian itu, maka penegakkan hukum disamakan artinya dengan istilah fungsionalisasi hukum, operasionalisasi hukum dan konkretisasi hukum. ${ }^{14}$

Upaya untuk menjadikan hukum berfungsi dan beroperasi sehingga terwujud secara konkret diperlukan suatu proses. Jadi dengan demikian, dapat diartikan bahwa penegakkan hukum adalah suatu proses bekerja dan berfungsinya hukum oleh aparat penegak hukum terhadap perilaku-perilaku yang secara formil maupun materil berlawanan dengan norma-norma hukum. ${ }^{15}$

Pada prosesnya, penegakan hukum memerlukan tiga komponen penting yang saling berinteraksi, bersinergi bahkan berinterdependensi antara komponen yang satu dengan komponen yang lainnya. Komponen yang dimaksud adalah Hukum (peraturan perundang-undangan); Aparat Penegak Hukum; dan Perilaku-perilaku yang secara formil-materiil berlawanan dengan norma hukum (kesadaran hukum masyarakat. Ketiga komponen penegakkan hukum di atas sesungguhnya tidak dapat dipisahkan dari ketiga komponen sistem hukum itu sendiri yaitu substansi hukum, struktur hukum dan budaya hukum yang juga satu dengan yang lainnya merupakan satu kesatuan (wholeness). Oleh karena itu untuk mencapai keberhasilan sistem hukum dan keberhasilan dalam penegakkannya, sangat bergantung pada eksistensi, artikulasi, performance dan iner capacity dari masing-masing komponen. ${ }^{16}$

Penegakkan hukum adalah kewajiban dari seluruh komponen masyarakat dan untuk itu, pemahaman tentang hak dan kewajiban menjadi syarat mutlak. Masyarakat bukan penonton bagaimana hukum ditegakkan akan tetapi masyarakat aktif berperan

14 Widiada Gunakarya, Pendekatan Sistem dan Kebijakan Dalam Penegakkan Hukum di Indonesia, Jurnal Wawasan Hukum, Vol. 7 No. 1 Maret 2002. hlm. 60.

15 Ibid.

16 Ibid. 
dalam proses penegakkan hukum. Paling sedikit ada 3 (tiga) perspektif berfungsinya hukum dalam masyarakat. Pertama perspekatif kontrol sosial dari hukum yang merupakan salah satui dari konsep-konsep yang biasanya paling banyak digunakan dalam studi-studi kemasyarakatan. Dalam perspektif ini, fungsi utama suatu sistem hukum bersifat integratif karena dimaksudkan untuk mengatur dan memelihara regularitas sosial dalam suatu sistem moral. Menurut Berger bahwa tidak ada masyarakat yang bisa hidup langgeng tanpa kontrol sosial dari hukum sebagai sarananya. ${ }^{17}$

Agar hukum dapat mengemban misi sebagai sosial kontrol, Menurut Talcot Parson, ada empat prasyarat fungsionalisasi dari suatu sistem hukum yaitu: 1) Masalah dasar legitimasi, yaitu menyangkut ideologi yang menjadi dasar penataan peraturan hukum; 2) Masalah hak dan kewajiban masyarakat yang menjadi sasaran regulasi hukum beserta proses hukumnya; 3) Masalah sanksi dan lembaga yang menerapkan sanksi tersebut; dan 4) Masalah kewenangan penegakkan aturan hukum.

Berkaitan dengan kepatuhan masyarakat terhadap sistem hukum yang berlaku, menurut Satjipto Rahardjo bahwa terdapat 4 (empat) syarat utama yang harus dipenuhi, diantaranya: 1) Penggambaran yang baik dari suatu situasi yang dihadapi; 2) Analisa terhadap nilai-nilai dan menentukan jenjang nilai-nilai; 3) Verifikasi dari kekuatan sosial yang menentukan bagaimana hukum digunakan, dihindari atau disalahgunakan, dan 4) Budaya hukum yang mendukung, karena tanpa budaya hukum sistem tidak akan berdaya. ${ }^{18}$

Maka dari pada itu, situasi institusi hukum akan menjadi hukum yang benarbenar diterima oleh masyarakat ataupun suatu komunitas tertentu sangat ditentukan oleh adanya budaya hukum masyarakat atau komunitas yang bersangkutan. Budaya hukum sebagaimana dikemukakan oleh Lawrence M. Friedman adalah sikap manusia terhadap hukum dan sistem hukum, kepercayaan, nilai pemikiran dan

17 Feter J. Berger, Invitations to Sociologies' Humanistic (Alih Bahasa oleh Dhakidae), Inti Sarana Aksara, Jakarta, 1985. hlm. 98.

18 Satjipto Rahardjo, Pemanfaatan Ilmu Sosial bagi Pengembangan Ilmu Hukum, Alumni, Bandung, 1977. hlm. 66. 
harapannya, dengan kata lain, budaya hukum adalah suasana pikiran sosial dan kekuatan sosial yang menentukan bagaimana hukum digunakan dihindari atau disalahgunakan. Tanpa budaya hukum, sistem hukum tidak berdaya. Oleh karena itu, situasi institusi hukum akan menajdi hukum yang benar-benar diterima dan digunakan oleh masyarakat ataupun suatu komunitas tertentu sangat ditentukan oleh budaya hukum masyarakat atau komunitas yang bersangkutan. ${ }^{19}$

Daniel S. Lev melihat bahwa meski budaya hukum adalah konsep yang relatif baru, namun cara praktis untuk memahaminya. Hal itu dapat disimak dari dua indikator, yaitu: 1) Nilai-nilai yang sangat erat berhubungan dengan sarana pengaturan sosial dan penanganan konflik. Nilai-nilai itu adalah dasar kultur dari sistem hukum dan sangat membantu dalam menentukan sistem pemberian tempat kepada lembaga-lembaga hukum, politik, religi dan lainnya pada setiap tempat dan waktu dalam suatu masyarakat, dan 2) Asumsi-asumsi dasar mengenai penyebaran dan penggunaan sumber daya yang ada dalam masyarakat, kebaikan dan keburukan sosial dan sebagainya, asumsi tersebut terdapat dalam pandangan mengenai ekonomi, politik, sosial yang terus berubah-ubah sesuai dengan perubahan masyarakat. ${ }^{20}$

Berbicara masalah penegakkan hukum secara umum maka mau tidak mau persoalan kepatuhan atau ketaatan merupakan salah satu unsur pokoknya. Hal ini disebabkan oleh taraf kepatuhan warga masyarakat terhadap aturan hukum, termasuk penegaknya. $^{21}$

Berkaitan dengan masalah budaya hukum masyarakat dalam upaya penegakkan hukum, maka keterlibatan masyarakat dalam pelaksanaan hukum merupakan salah satu bentuk hubungan sinergis antara budaya dengan hukum. Dengan kata lain, ketaatan dan ketidak taatan seseorang sangat dipengaruhi oleh

19 Lawrence M Friedman, American Law Introduction, Alih Bahasa oleh Wisnu Basuki, PT. Tata Nusa, Jakarta, 2001. hlm. 8.

20 Daniel S. Lev, Lembaga Peradilan dan Budaya Hukum di Indonesia, A.A.G. Peters (Ed) Hukum dan Perkembangan Sosial, Buku II, Pustaka Sinar Harapan, Jakarta, 1988. hlm. 193.

21 Soerdjono Soekanto, Suatu Tinjauan Sosiologi Hukum Terhadap Masalah-Masalah Social, Citra Aditya Bhakti, Bandung, 1985. hlm. 52. 
budaya hukum yang telah hidup dalam komunitas masyarakat tersebut. Perbedaan pendidikan, jenis kelamin, suku, kebangsaan, pendapatan dan lain-lain sangat mempengaruhi budaya hukum seseorang, karena komponen hukum selain meliputi struktur dan substansi, yang lebih penting adalah budaya hukum. ${ }^{22}$

Sebagian masyarakat sadar bahwa hukum harus ditaati karena hukum itu sendiri memberikan manfaat dan faedah bagi dirinya. Berkaitan dengan masalah penegakkan hukum melalui berbagai proses antara lain melalui pendekatan kebijakan formulatif maupun implementatif, maka dapat dikatakan bahwa:

1. Keberhasilan suatu peraturan perundang-undangan tergantung pada penerapannya. Apabila penegakkan hukum tidak dapat berfungsi dengan baik, maka peraturan perundang-undangan yang bagaimanapujn baiknya, akan memberikan arti tidak sesuai dengan tujuannya;

2. Putusan-putusan dalam rangka penegakkan hukum merupakan instrumen kontrol bagi ketepatan dan kekurangan suatu peraturan perundang-undangan. Putusan-putusan tersebut merupakan masukan bagi pembaharuan atau penyempurnaan peraturan perundang-undangan;

3. Penegakkan hukum merupakan dinamisator peraturan perundang-undangan. Melalui putusan dalam rangka penegakkan hukum peraturan perundangundangan menjadi hidup dan diterapkan sesuai dengan kebutuhan dan perkembangan masyarakat. Bahkan peraturan perundang-undangan yang kurang baik akan tetap mencaai sasaran atau tujuan di tangan para penegak hukum yang baik. $^{23}$

4. Keberhasilan suatu hukum dan keberhasilan dalam penegakkan hukum tidak terlepas dari persyaratan dan peran serta perilaku hukum masyarakat yang baik. Perilaku masyarakat akan baik apabila hukumnya aspiratif dan penegak hukumnya responsif. ${ }^{24}$

Penegakkan hukum hanya dapat berjalan dengan baik apabila seluruh komponen berjalan sesuai dengan kapasitas dan fungsinya. Hal ini masih sulit untuk dilaksanakan karena masih besarnya kepentingan pribadi yang melekat dalam setiap tahapan proses penegakkan hukum.

22 Esmi Warasih, Pemberdayaan Masyarakat Dalam Rangka Mewujudkan Tujuan Hukum, Makalah pada Pidato Pengukuhan Guru Besar Madya Ilmu Hukum, FH UNDIP, Semarang, 2001. hlm. 11.

23 Bagir Manan, Politik Perundang-undangan, Makalah disajikan pada Penataran Dosen FH/STH se Indonesia, Ditjen Dikti, Bogor, 26 September s.d 16 Oktober 1993, hlm. 4-5.

24 Widiada Gunakarya, Op. Cit. hlm. 68. 


\section{B. Tentang Sistem Peradilan Pidana di Indonesia.}

Sistem Peradilan Pidana adalah sistem yang dibuat untuk menanggulangi masalah-masalah kejahatan yang dapat mengganggu ketertiban dan mengancam rasa aman masyarakat, merupakan salah satu usaha masyarakat untuk mengendalikan terjadinya kejahatan agar berada dalam batas-batas toleransi yang dapat diterima. Pelaksanaan peradilan pidana adalah upaya untuk menanggulangi kejahatan yang terjadi di masyarakat dengan mengajukan para pelaku kejahatan ke pengadilan sehingga menimbulkan efek jera kepada para pelaku kejahatan dan membuat para calon pelaku kejahatan berpikir dua kali sebelum melakukan kejahatan. ${ }^{25}$

Menurut Muladi, sistem peradilan pidana sesuai dengan makna dan ruang lingkup sistem dapat bersifat phisik dalam arti sinkronisasi struktural (structural syncronization) dalam arti keselarasan mekanisme administrasi peradilan pidana, dapat pula bersifat substansial (substancial syncronization) dalam kaitannya dengan hukum positif yang berlaku, dan dapat pula bersifat kultural (cultural syncronization) dalam arti menghayati pandangan, sikap, dan falsafah yang secara menyeluruh mendasari jalannya sistem peradilan pidana. ${ }^{26}$

Sistem Peradilan Pidana yang Terpadu (SPPT) atau Integrated Criminal Justice Sistem (ICJS) merupakan unsur hukum pidana yang sangat penting dalam kerangka penegakan hukum pidana materil. Philip. P. Purpura menyatakan bahwa sistem peradilan pidana (criminal justice sistem) merupakan suatu sistem yang terdiri dari Kepolisian, Kejaksaan, Pengadilan, dan Lembaga Pemasyarakatan yang bertujuan untuk melindungi dan menjaga ketertiban masyarakat, mengendalikan kejahatan, melakukan penangkapan, dan penahanan terhadap pelaku kejahatan, memberikan batasan bersalah atau tidaknya seseorang, memidana pelaku yang bersalah dan melalui komponen sistem secara keseluruhan dapat memberikan perlindungan hukum terhadap hak-hak terdakwa. ${ }^{27}$

25 Abdussalam dan DPM Sitompul, Sistem Peradilan Pidana, Restu Agung, Jakarta, 2007. hlm. 4.

26 Muladi, Kapita Selekta Sistem Peradilan Pidana, Undip, Semarang, 1995. hlm.13.

27 Sidik Sunaryo, Kapita Selekta Sistem Peradilan Pidana, UMM Press, Malang, 2005. hlm. 2. 
Pelaksanaan sistem peradilan pidana masih memiliki banyak kelemahan dalam berbagai aspek. Kelemahan tersebut salah satunya bersumber dari perangkat hukum positif yang belum sepenuhnya mendukung terciptanya sistem peradilan pidana yang transparan, akuntabel. Kelemahan-kelemahan tersebut dapat turut mempengaruhi kegagalan sistem peradilan pidana dalam mencapai tujuannya. Pada gilirannya, akan menghambat upaya pengendalian kejahatan di masyarakat karena pada dasarnya, menurut Mardjono Reksodiputro, sistem peradilan pidana merupakan salah satu usaha masyarakat untuk mengendalikan terjadinya kejahatan agar berada dalam batas toleransi yang dapat diterimanya. ${ }^{28}$

Tujuan Sistem Peradilan Pidana menurut Muladi dapat dikategorikan sebagai berikut, tujuan jangka pendek, tujuan jangka menengah, dan tujuan jangka panjang. ${ }^{29}$

Dengan bahasa yang lebih sederhana Loebby Loqman berpendapat tujuan sistem peradilan pidana adalah menghilangkan kejahatan (bukan penjahatnya) untuk mencapai suatu masyarakat yang terbebas dari kejahatan. ${ }^{30}$

\section{Peranan Advokat Dalam Sistem Peradilan Pidana di Indonesia.}

Istilah advokat jauh lebih dahulu dikenal daripada istilah Bantuan Hukum atau penasehat hukum. Istilah penasehat hukum atau bantuan hukum memang lebih tepat dan sesuai dengan fungsinya sebagai pendamping tersangka atau terdakwa dalam pemeriksaan daripada istilah pembela. ${ }^{31}$

Bagi sebagian orang, istilah penasehat hukum, bantuan hukum dan pengacara jauh lebih popular dan memasyarakat. Hal ini terkait dengan pengertian yang lebih sederhana dari kedua istilah itu di mana sangat mudah untuk mengartikannya. Selain alasan tersebut, dalam Undang-Undang Nomor 8 Tahun 1981 Tentang Kitab Undang-

28 Mardjono Reksodiputro, Kriminologi dan Sistem Peradilan Pidana, Pusat Pelayanan Keadilan dan Pengabdian Hukum Universitas Sumatera Utara, 1994. hlm. 140.

29 Muladi dalam Petrus Irawan P dan Pandapotan Simorangkir, Lembaga Pemasyarakatan dalam Perspektif Sistem Peradilan Pidana, Pustaka Sinar Harapan, Jakarta, 1995. hlm. 54.

30 Loebby Loqman, Hak Asasi Manusia dalam Hukum Acara Pidana. Datacom, Jakarta, 2002. hlm. 22-23.

31 Andi Hamzah, Hukum Acara Pidana Indonesia, Sinar Grafika, Jakarta, 2004. hlm. 86. 
undang Hukum Acara Pidana (selanjutnya disebut KUHAP) juga menggunakan istilah bantuan hukum. Pasal 37 KUHAP dengan tegas menyebutkan bahwa, “ Dalam perkara pidana seorang tersangka terutama sejak saat penangkapan dan/atau penahanan berhak menghubungi dan meminta bantuan hukum".

Istilah advokat telah dikenal sejak 2000 tahun yang lalu, dijuluki sebagai officium nobile atau profesi yang mulia, sarat dengan idealism sebab mengabdikan dirinya kepada kepentingan masyarakat, bukan kepada dirinya sendiri, membela masyarakat untuk memperjuangkan keadilan dan kebenaran. Berbeda dengan penegak hukum lain (polisi, jaksa dan hakim), advokat tidak terikat pada hierarki birokratis sehingga memungkinkan lebih luas bergerak mengikuti arus social. Advokat lebih akrab berhubungan dengan masyarakat sehingga lebih jeli melihat masalah hukum maupun hak asasi manusia yang terjadi di tengah masyarakat. Advokat harus selalu menyuarakan keadilan dan peka terhadap permasalahan social berdimensi hukum disekitarnya. ${ }^{32}$

Advokat merupakan penegak hukum dan sebagai profesi yang bebas, mandiri dan bertanggung jawab dalam menegakkan hukum yang dijamin oleh Undangundang. Itu berarti bahwa advokat memiliki hak, kewajiban dan tanggung jawab sesuai dengan aturan perundang-undangan advokat. Pasal 17 Undang-Undang Nomor 18 Tahun 2003 tentang Advokat memberikan hak kepada advokat untuk keperluan pembelaan kliennya, yaitu hak memperoleh informasi, data dan dokumen lainnya baik dari instansi pemerintah maupun pihak lain yang berkaitan dengan kepentingan tersebut yang diperlukan untuk pembelaan kepentingan kliennya sesuai dengan peraturan perundang-undangan. ${ }^{33}$

Undang-Undang Nomor 18 Tahun 2003 merupakan Payung hukum yang memayungi advokat dalam melaksanakan tugas-tugas profesinya. Beberapa pengertian penting untuk diketahui berkaitan dengan masaah advokat ini antara lain:

32 Denny Kailimang, Mantapkan Persatuan dan Profesionalisme Advokat Sebagai Penegak Hukum dan Profesi Terhormat, Makalah, disampaikan pada Rakernas XII AAI, Pontianak, 18-19 Mei 2007. hlm. 2.

33 Ibid. hlm. 4. 
1. Advokat adalah orang yang berprofesi memberi jasa hukum, baik di dalam maupun di luar pengadilan yang memenuhi persyaratan berdasarkan ketentuan Undang-undang.

2. Jasa Hukum adalah jasa yang diberikan advokat berupa memberikan konsultasi hukum, bantuan hukum, menjalankan kuasa, mewakili, mendampingi, membela dan melakukan tindakan hukum lain untuk kepentingan klien.

3. Bantuan Hukum adalah jasa hukum yang diberikan oleh advokat secara Cuma-Cuma kepada klien yang tidak mampu.

Fungsi advokat dalam penegakan sistem hukum mempunyai peran yang sangat penting. Melalui jasa hukum yang diberikan advokat menjalankan tugas profesi demi tegaknya hukum dan keadilan untuk kepentingan masyarakat pencari keadilan. Peran advokat dilakukan baik di dalam maupun di luar pengadilan. Di dalam Pengadilan, advokat merupakan salah satu unsur sistem peradilan demi terciptanya proses peradilan yang bebas dan tidak memihak serta berjalannya prinsip due process of law. Sedangka di luar pengadilan advokat memberikan jasa konsultasi, negosiasi, pembuatan kontrak serta melakukan aktivitas yang meningkatkan keberdayaan hukum masyarakat. ${ }^{34}$

Sejalan dengan terpuruknya wibawa hukum dan pengadilan, provesi advokat sekarang berada dalam tahap yang sangat mengkhawatirkan. Keterpurukan profesi adfokat tidak terlepas dari lemahnya asosiasi advokat. Profesi advokat sebagai profesi terhormat selalu ditakuti pada setiap pemerintahan otoriter. Para advokat dan asosiasi advokat berkewajiban menjalankan fungsi kritik dan kontrol. ${ }^{35}$

Disadari atau tidak, ukuran menguntungkan atau tidak menguntungkan suatu perkara dipandang hanya dari kacamata politis dan ekonomis. Hal ini dianggap sah selama standar formal telah ditempuh. Hal ini diperparah dengan praktik-praktik curang aparat penegak hukum itu sendiri yang dikenal dengan istilah "mafia peradilan". Praktik-praktik korupsi yang sering dikategorikan sebagai "judicial corruption" disebabkan ketidakmandirian lembaga peradilan dan institusi hukum

34 Jimly Asshiddiqie, Kitab Advokat Indonesia, PT. Alumni, Bandung, 2007.

35 Indra Sahnun Lubis, Op. Cit. hlm. 4. 
(Polisi, Jaksa Penuntut Umum, Advokat/Pengacara Dan Hakim). Tidak dapat dipungkiri bahwa advokat pun secara langsung atau tidak langsung turut menciptakan terjadinya mafia peradilan dan judicial corruption. Proses penegakkan hukum yang menjadi kewajiban dan tanggung jawab aparat penegak hukum dan aparat peradilan telah berada dalam situasi yang sangat buruk.

Profesi advokat sebagai salah satu profesi hukum bertujuan untuk mewujudkan ketertiban berkeadilan yang memungkinkan manusia dapat menjalani kehidupannya dengan wajar. Pengembanan profesi advokat pada dasarnya mencakup empat bidang, yaitu: 1) Penyelesaian konflik secara formal yaitu lewat jalur peradilan; 2) Pencegahan konflik lewat rancangan hukum, opini dan nasehat hukum; 3) Penyelesaian konflik secara informal lewat mediasi dan negosiasi; dan 4) Penerapan hukum di luar konflik. ${ }^{36}$

Pengembanan profesi Advokat harus selalu dilakukan dengan mengacu pada cita-cita hukum atau rechtsidee (ketertiban, prediktabilitas, Kepastian hukum, kegunaan sosial dan keadilan) demi pengayoman pada setiap manusia yang berakar dalam penghormatan atas martabat manusia. Sebagai bagian dari penegak hukum, advokat mempunyai kedudukan yang sama dengan penegak-penegak hukum lainnya seperti Polisi, Jaksa penuntut umum dan Hakim. Sebagai bagian dari aparat penegak hukum, advokat mempunyai hak dan kewajiban yang secara tersendiri di atur dalam Undang-Undang Nomor 18 Tahun 2003 Pasal 14 sampai dengan Pasal 17.

Berkaitan dengan kewajiban-kewajiban Advokat, khususnya terhadap kepentingan kliennya, Undang-undang Advokat mengatur sebagai berikut, 1) Advokat dalam menjalankan profesinya dilarang membedakan perlakuan terhadap kliennya berdasarkan jenis kelamin, agama, politik, keturunan, rasa tau latar belakang social dan budaya; 2) Advokat tidak dapat diidentikan dengan kliennya dalam membela perkara klien oleh pihak yang berwenang dan/atau masyarakat; 3) Advokat wajib merahasiakan segala sesuatu yang diketahui atau diperoleh dari kliennya

36 Ibid. 
sehubungan profesinya, kecuali ditentukan lain oleh undang-undang; 4) Advokat wajib memberikan bantuan hukum secara Cuma-Cuma kepada pencari keadilan yang tidak mampu; 5) Advokat wajib untuk tunduk dan patuh terhadap kode etik provesi advokat; 6) Advokat berhak atas kerahasiaan hubungannya dengan klien termasuk perlindungan atas berkas dan dokumennya terhadap penyitaan dan pemeriksaan dan perlindungan terhadap penyadapan atas komunikasi elektronik advokat; 7) Advokat berhak menerima honorarium atas jasa hukum yang telah diberikan kepada Kliennya; dan 8) Besarnya honorarium atas jasa hukum sebagaimana dimaksud, ditetapkan berdasarkan kesepakatan kedua belah pihak.

Peran dan fungsi advokat dalam pelaksanaan sistem peradilan pidana di Indonesia jelas memegang peranan yang sangat penting guna tegaknya due process of law. Dengan berbekal kompetensi yang teruji serta moralitas dan etika yang baik, advokat dengan serangkaian keintimewaan yang diberikan oleh undang-undang dapat menjadi ujung tombak dalam mewujudkan cita-cita hukum yang lebih tinggi yakni keadilan.

\section{PENUTUP.}

\section{A. Kesimpulan.}

1. Upaya untuk menjadikan hukum berfungsi dan beroperasi sehingga terwujud secara konkret diperlukan suatu proses. Jadi dengan demikian, dapat diartikan bahwa penegakkan hukum adalah suatu proses bekerja dan berfungsinya hukum oleh aparat penegak hukum terhadap perilaku-perilaku yang secara formil maupun materil berlawanan dengan norma-norma hukum.

2. Dalam prosesnya, penegakan hukum memerlukan tiga komponen penting yang saling berinteraksi, bersinergi bahkan berinterdependensi antara komponen yang satu dengan komponen yang lainnya.

3. Mengacu pada Undang-Undang Nomor 18 Tahun 2003, advokat diberikan kebebasan dalam menjalankan profesinya disamping hak-hak lain yang diberikan oleh undang-undang antara lain hak imunitas (kekebalan), hak untuk 
memperoleh informasi sehubungan dengan pembelaan kliennya, dan hak untuk memperoleh honorarium. Disamping itu, kewajiban-kewajiban advokat yang membedakannya dengan profesi hukum yang lainnya antara lain: kewajiban untuk menjaga rahasia kliennya, kewajiban untuk memberikan bantuan hukum secara cuma-cuma, dan kewajiban untuk patuh terhadap kode etik profesi advokat. Advokat memegang peranan penting dalam sistem peradilan pidana di Indonesia, di mana advokat sebagai pihak yang memperjuangkan Hak Asasi Manusia (HAM) dari kliennya. Meskipun advokat bertindak untuk membela kepentingan kliennya, tetapi pada dasarnya advokat sesuai dengan Undang-Undang Nomor 18 Tahun 2003 adalah sebagai penegak hukum dengan demikian advokat dituntut untuk mewujudkan citacita hukum yakni kepastian hukum dan keadilan.

\section{B. Saran.}

1. Advokat dalam menjalankan profesinya, hendaknya tetap berpegang teguh pada kode etik profesi Advokat dan ketentuan tentang Dewan Kehormatan Organisasi Advokat sebagai hukum tertinggi dalam melaksanakan aktifitas profesinya.

2. Bagi masyarakat hendaknya memandang advokat secara jernih, dan tidak mengidentikan advokat dengan klien yang sedang dibelanya. Karena advokat bukan membela kesalahan klien ataupun mencari alasan pembenar atas kesalahan klien. Tetapi aktifitas profesi advokat tidak terlepas dari tujuan dan cita-cita hukum yakni kepastian hukum dan keadilan.

3. Selain berperan sebagai pendamping bagi klien-klien, advokat merupakan bagian dari penegak hukum. Untuk itu hendaknya advokat dapat menjalankan tugas dan fungsi secara seimbang antara pembela kepentingan klien dan kepentingan hukum 


\section{DAFTAR PUSTAKA}

\section{A. Buku.}

Abdussalam dan DPM Sitompul, Sistem Peradilan Pidana, Restu Agung, Jakarta, 2007.

Andi Hamzah, Hukum Acara Pidana Indonesia, Sinar Grafika, Jakarta, 2004.

Arief Sidharta, Pelaksanaan Kode Etik profesi Hukum Di Indonesia, Pusat Studi Hukum dan Kebijakan Indonesia, Jakarta, 2004.

Daniel S. Lev, Hukum dan Politik di Indonesia, Penerbit LP3ES, Jakarta, 1990.

Lembaga Peradilan dan Budaya Hukum di Indonesia, A.A.G. Peters (Ed) Hukum dan Perkembangan Sosial, Buku II, Pustaka Sinar Harapan, Jakarta, 1988.

Feter J. Berger, Invitations to Sociologies' Humanistic (Alih Bahasa oleh Dhakidae), Inti Sarana Aksara, Jakarta, 1985.

Jimly Asshidiqie, Kitab Advokat Indonesia, Penerbit Ikatan Advokat Indonesia, Jakarta, 2007.

Lawrence M Friedman, American Law Introduction, Alih Bahasa oleh Wisnu Basuki, PT. Tata Nusa, Jakarta, 2001.

Loebby Loqman, Hak Asasi Manusia dalam Hukum Acara Pidana. Datacom, Jakarta, 2002.

Muladi, dalam Petrus Irawan $\mathrm{P}$ dan Pandapotan Simorangkir, Lembaga Pemasyarakatan dalam Perspektif Sistem Peradilan Pidana, Pustaka Sinar Harapan, Jakarta, 1995.

, Hak Asasi Manusia, Politik dan Sistem Peradilan Pidana, Badan Penerbit Universitas Diponegoro, Semarang, 1997.

, Kapita Selekta Sistem Peradilan Pidana, UNDIP, Semarang, 1995.

Satjipto Rahardjo, Pemanfaatan Ilmu Sosial bagi Pengembangan Ilmu Hukum, Alumni, Bandung, 1977.

Sidik Sunaryo, Kapita Selekta Sistem Peradilan Pidana, UMM Press, Malang, 2005. 
Soerdjono Soekanto, Suatu Tinjauan Sosiologi Hukum Terhadap Masalah-Masalah Social, Citra Aditya Bhakti, Bandung, 1985.

, Faktor-faktor yang Mempengaruhi Penegakan Hukum, PT. Rajawali, Jakarta, 1983.

\section{B. Peraturan Perundang-Undangan.}

Undang-Undang Dasar 1945.

Undang-Undang Nomor 1 Tahun 1946 Tentang Kitab Undang-Undang Hukum Pidana.

Undang-undang RI Nomor 8 Tahun 1981 Tentang Kitab Undang-Undang Hukum Acara Pidana

Undang-Undang Nomor 18 Tahun 2003 Tentang Advokat

C. Makalah, Jurnal, Artikel, Majalah, Internet, dan Lain-lain.

Bagir Manan, Politik Perundang-undangan, Makalah disajikan pada Penataran Dosen FH/STH se Indonesia, Ditjen Dikti, Bogor, 26 September s.d 16 Oktober 1993.

Barda Nawawi Arief, Masalah penegakan Hukum dan Kebijakan Penaggulangan Kejahatan, Makalah pada Program Magister Ilmu Hukum Universitas Diponegoro, Semarang, 2000.

, Sistem Pemidanaan Dalam Ketentuan Umum Buku I RUU KUHP 2004, "Makalah", disajikan pada acara Silaturahmi Akademik, Sekolah Tinggi Hukum Bandung, Bandung 12 Juli 2005.

Denny Kailimang, Mantapkan Persatuan dan Profesionalisme Advokat Sebagai Penegak Hukum dan Profesi Terhormat, Makalah, disampaikan pada Rakernas XII AAI, Pontianak, 18-19 Mei 2007.

, Advokat dan Mahkamah Konstitusi, Makalah, disampaikan pada seminar Nasional Peranan dan Kedudukan Mahkamah Konstitusi Dalam Menunjang Sistem Hukum dan Demkrasi di Indonesia, Bandung, 2004.

Esmi Warasih, Pemberdayaan Masyarakat Dalam Mewujudkan Tujuan Hukum, Pidato Pengukuhan Guru Besar Madya Dalam Ilmu Hukum, Fakultas Hukum Universitas Diponegoro, Semarang, 14 April 2002.

Fred B.G. Tambunan, Kode Etik Advokat Indonesia, Makalah, pada Proceeding Workshop Kode Etik Advokat Indonesia, Langkah Menuju Penegakkan,, PSHK, Jakarta, 2004. 
Mardjono Reksodiputro, Kriminologi dan Sistem Peradilan Pidana, Pusat Pelayanan Keadilan dan Pengabdian Hukum Universitas Sumatera Utara, 1994.

Soedjono Dirdjosisworo, Pelaksanaan Misi Advokat Dalam Peradilan Pidana, Makalah Pada Pelatihan Calon Advokat, Bandung, 2005.

Widiada Gunakaya, Pendekatan Sistem dan Kebijakan Dalam Penegakan Hukum di Indonesia, Jurnal Wawasan Hukum, Vol. 7 No. 1 Maret 2002. 